\title{
Comparative effects of native frugivores and introduced rodents on seed germination in New-Caledonian rainforest plants
}

\author{
Quiterie Duron • Oriana Garcia-Iriarte • \\ Fabrice Brescia • Eric Vidal
}

\begin{abstract}
Native frugivores play an important role in native plant community dynamics by participating in seed dispersal. Today many island forests are invaded by introduced omnivores, such as rats, but their role in dispersing native plants is still little known. Here, we evaluated whether native seeds from New-Caledonian rainforests can germinate after passing through an invasive rat digestive tract and compared seed germinability and germination time between seeds ingested by invasive rats and native frugivores. We offered native fruits of Ficus racemigera and $\mathrm{Fr}$ eycinetia sulcata to the rats Rattus rattus and $R$. exulans, three flying foxes Pteropus spp. and the pigeon Ducula goliath. Our results showed that seeds can germinate after passing through an invasive rat digestive tract, and suggest that rats can disperse seeds of both plant species. However, invasive rats may be less efficient than native frugivores, as more seeds were destroyed when passing through rat digestive tracts than through native frugivores, and because
\end{abstract}

Q. Duron $(\varangle) \cdot$ O. Garcia-Iriarte · E. Vidal Institut Méditerranéen de Biodiversité et d'Ecologie marine et continentale (IMBE), Aix Marseille Univ, Univ Avignon, CNRS, IRD, IMBE, Centre IRD Nouméa - BP A5, 98848 Nouméa Cedex, New Caledonia, France e-mail: quiterie.duron@ird.fr

\section{F. Brescia}

Institut Agronomique Néo-Calédonien (IAC), Diversités biologique et fonctionnelle des écosystèmes terrestres - BP 73, 98890 Païta, New Caledonia, France germinability was lower and germination time was longer for seeds passing through invasive rats than through native frugivores. The reduced efficiency of rats may result from their generalized diet, the structure of their digestive tract, and/or their feeding behavior. In New-Caledonian rainforests, dispersal services on both plant species are likely well fulfilled by flying foxes and Ducula pigeons, but rats do not seem to be as efficient dispersers. Consequently, management measures to protect native frugivores should help to conserve seed dispersal services.

Keywords Seed dispersal - Seed destruction · Rattus · Flying foxes · Frugivorous pigeon

\section{Introduction}

Seed dispersal is a key process in plant community dynamics as it allows species to colonize new areas and avoid competition with siblings, predation, and spread of pathogens (Traveset et al. 2014). Frugivorous vertebrates, especially mammals and birds, play an important role in seed dispersal (Jordano 2014). Vertebrates disperse seeds from 70 to $94 \%$ of all woody species in tropical rainforests, and seeds from 65 to $74 \%$ in subtropical humid forest (Jordano 2014). One of the main ways for frugivores to disperse seeds is by endozoochory, i.e. by the ingestion and excretion of seeds. While frugivores benefit by obtaining energy 
and nutrients from the fruit pulp, endozoochory benefits the plant by facilitating the transport of seeds away from the parent plant location, and can also help germination (Traveset 1998; Reid and Armesto 2011; Jordano 2014). Passage through a frugivore's digestive tract can enhance germination success by abrasion of the seed coat and the removal of the pulp (Barnea et al. 1991; Traveset 1998; Jordaan et al. 2011). Endozoochory is crucial for the dispersal of many fleshy fruited plants (Traveset et al. 2014) and it is recognized that these mutualistic interactions are currently threatened by human disturbance and the drivers of global environmental change, such as invasive species (Tylianakis et al. 2008; Markl et al. 2012). On islands, endozoochory relations are even more particularly prone to be disturbed by invasive species because of the uniqueness and the low diversity of native frugivore assemblages (Traveset and Richardson 2006; Traveset et al. 2014).

Invasive species can affect dispersal processes negatively by disrupting plant-seed disperser interactions (Kelly et al. 2006; Traveset and Richardson 2006), or positively by compensating when native seed dispersers are few or have disappeared (KaiserBunbury et al. 2010; Pattemore and Wilcove 2011). For example, the efficiency of introduced birds as native seed dispersers was already demonstrated in Hawaiian forests (Foster and Robinson 2007), and the capacity of invasive rats to disperse small seeds of both native and invasive plants was studied in New Zealand and Hawaiian forests (Williams et al. 2000; Grant-Hoffman and Barboza 2010; Shiels 2011; Shiels and Drake 2011). However, invasive species can belong to groups or taxa that did not exist among native species, in particular flightless terrestrial mammals that have historically been absent from most oceanic islands (Lever 1985; Whittaker and Fernandez-Palacios 2007; Scheiner and Willig 2011) and did not evolve together with native plant species (Nogales et al. 2005). These two particularities may result in lower seed dispersal performances of invasive vertebrates versus native vertebrates. The effects of invasive species on seed dispersal can be ambiguous and our objective was to study the relative capacities of invasive rats and native frugivores to facilitate the dispersal process in an island system.

On islands, native vertebrate frugivores include birds, flying foxes and many Squamata but few terrestrial mammals (Olesen and Valido 2004;
Nogales et al. 2005). Nonetheless, most islands have been invaded by exotic terrestrial mammals (Courchamp et al. 2003; Blackburn et al. 2004), some of them being partly frugivorous like pigs, deer, rabbits and rats. These species can strongly affect plant communities and mutualisms directly, through predation and competition (Traveset and Richardson 2006; Traveset et al. 2009). Invasive rats (Rattus spp.), and particularly the Black rat Rattus rattus, even if their diet is omnivorous and depends on seasonal resource availability (Caut et al. 2008; Shiels et al. 2014), feed mainly on plant material (seeds, fruits, vegetative parts; Sugihara 1997; Meyer and Butaud 2008; GrantHoffman and Barboza 2010; Shiels et al. 2012). Invasive rats are generally considered to be seed predators and are known for their detrimental effects on plants (Meyer and Butaud 2008; Grant-Hoffman and Barboza 2010; Shiels and Drake 2011), but they may also have positive effects by acting as seed dispersers (Williams et al. 2000; Grant-Hoffman and Barboza 2010). When eating fleshy fruits, small seeds may pass intact through the rat digestive tract and may be dispersed by endozoochory (Traveset 1998; Williams et al. 2000; Bourgeois et al. 2005; GrantHoffman and Barboza 2010; Shiels 2011). The length limit of seeds reported to pass intact through the rat digestive tract was about $2.0-2.5 \mathrm{~mm}$ for $R$. rattus and $0.11 \mathrm{~mm}$ for the Pacific rat $R$. exulans (Williams et al. 2000; Shiels 2011). However, our knowledge on the capacity of invasive rats to participate in native seed dispersal is still limited (Shiels and Drake 2011).

Since most of the world's islands $(82 \%)$ are now occupied by invasive rats (Atkinson 1985; Capizzi et al. 2014), a better understanding of the role of invasive rats in their host ecosystems is essential before considering their management. In the New Caledonia archipelago, two common invasive rats $R$. exulans and $R$. rattus coexist in all natural areas from sea level to $1629 \mathrm{~m}$ a.s.l (Beauvais et al. 2006). $R$. exulans reached the archipelago 3000 years ago with the initial Melanesian settlements, while $R$. rattus arrived with European colonization about 150 years ago (Beauvais et al. 2006). New Caledonia is listed as one of 35 biodiversity hotspots with exceptional rates of floral endemism that reach $83.2 \%$ in rainforests (Mittermeier et al. 2011; Morat et al. 2012). A study conducted on 123 new-Caledonian rainforest tree species revealed that $72 \%$ have adaptations for dispersal by vertebrates (Carpenter et al. 2003), and 
pinpointed the importance of conserving native frugivorous species to maintain dispersal processes of endemic plants. Native frugivores on New Caledonia's main island (Grande Terre) include 47 species of Squamata (42 gekkos and 5 skinks) (Hervé Jourdan, personal communication), 15 species of birds (Barré and Dutson 2000; Tassin et al. 2010), and four species of flying foxes (Flannery 1995), and may have been more diversified before human and rat colonization (Balouet and Olson 1989; Balouet 1991).

Few comparisons of the effects of passage through invasive versus native species' digestive tracts on seed germination have been conducted (Nogales et al. 2005). To the best of our knowledge, only one study conducted in the Cook Islands, on Ficus prolixa, compared the differences in native seed germination after passage through native frugivorous (bird and flying foxes) and invasive rat species digestive tracts (Staddon et al. 2010). Therefore, the presence of both native frugivores (birds and flying foxes) and invasive rats in New-Caledonian rainforest represented a unique opportunity to test their relative effects on seed germination. In this study, we focused on the first steps of dispersal by endozoochory i.e. seed survival and germination after passing through the digestive tract, and compared these in native frugivores and invasive rats. Our aims were to evaluate whether seeds can survive and germinate after passing through the invasive rat digestive tract and to compare seed germination effectiveness (germinability and germination time), between non ingested seeds and seeds ingested by native frugivores or invasive rats.

\section{Methods}

Fruits and seeds characteristics

Two native plant species were selected based on morphological, ecological, and phenological criteria and their accessibility: Ficus racemigera (Bureau, Moraceae) and Freycinetia sulcata (Warb., Pandanaceae). Their fruits are known to be eaten by both native frugivorous birds and flying foxes, as well as by invasive rats in New Caledonia (M. Boissenin and H.Vandrot, personal communication). Moreover, species of the genera Ficus and Freycinetia are known to be eaten by flying foxes (Parsons et al. 2006; Nakamoto et al. 2009; Heer et al. 2010) and bats (Burrows 1996) in other parts of the world. Ficus species were also noted as the most common food source for Ducula galeata in the Marquesas archipelago (Blanvillain and Thorsen 2003) and are consumed by Ducula pacifica in Tonga (McConkey et al. 2005). Ducula goliath was observed feeding on Freycinetia arborea, a species closely related to Freycinetia sulcata, in Mont Panié, New Caledonia (personal observation). Seeds of both the genera Ficus and Freycinetia were found in $R$. rattus and $R$. exulans stomach and caecum contents for specimens collected in Mont Panié rainforest area, and these results oriented our choice to study germination of these two plant species. Ficus and Freycinetia have small seeds $(<1.5 \mathrm{~mm})$ which may allow dispersal by endozoochory by both native frugivores and invasive rats (Williams et al. 2000; Shiels 2011; Shiels and Drake 2011). For both species, a sample of fruits and seeds was weighed with a precision balance Mettler AE 240 (precision $0.1 \mathrm{mg}$ ), fruits were measured using a digital caliper (precision $0.001 \mathrm{~mm}$ ) and seeds from binocular photography with "Image J" software (Table 1).

Ficus racemigera (hereafter Ficus) is a species of tree endemic to New Caledonia and Vanuatu, found in dense rainforests at various elevations. The fig "fruit", called a syconium, is a multiple pseudocarp, which includes several achene fruits. Each achene is made up of a seed surrounded by its calyx and fixed by a pedicel to the syconium fleshy receptacle. Each fig contains more than 300 small brown and rounded seeds (length $1.03 \pm 0.89 \mathrm{~mm}$; width $0.72 \pm 0.84 \mathrm{~mm}$ ). Mature fruits, selected for their reddish color and smooth texture, were collected in rainforest areas on Mont Koghi $\left(22^{\circ} 10^{\prime} 38^{\prime \prime} \mathrm{S}, 166^{\circ} 30^{\prime} 30^{\prime \prime} \mathrm{E}, 450 \mathrm{~m}\right.$ a.s.l. $)$ in February and March 2015. Freycinetia sulcata (hereafter Freycinetia) is a hemiepiphyte native liana. Their fruits, or berries, are gathered in a yellow scented infructescence. Each infructescence contains more than 1000 seeds (length $1.15 \pm 0.08 \mathrm{~mm}$; width $0.28 \pm 0.03 \mathrm{~mm}$ ), which are covered by a thick mucilaginous flesh. Seeds are slightly curved with hyaline membrane margins on each side (Stone et al. 1998). Mature fruits, distinguished by their yellow color and their strong scent, were collected on Mont Panié $\left(20^{\circ} 37^{\prime} 30^{\prime \prime} \mathrm{S}, 164^{\circ} 46^{\prime} 56^{\prime \prime} \mathrm{E}, 650 \mathrm{~m}\right.$ a.s.l.) in March and May 2015. 
Table 1 Summary of fruit and seed color, size, weight, and numbers for Ficus racemigera and Freycinetia sulcata. Fruits measures for Freycinetia were made on the whole inflorescence

\begin{tabular}{lll}
\hline & Ficus racemigera & Freycinetia sulcata \\
\hline Family & MORACEAE & PANDANACEAE \\
Life form & Shrub or tree & Secondary hemiepiphyte \\
Fruit color & Red & Yellow \\
Fruit length $(\mathrm{mm})$ & $14.42 \pm 1.47(n=33)$ & $81.28 \pm 11.1(n=21)$ \\
Fruit width $(\mathrm{mm})$ & $16.09 \pm 1.85(n=33)$ & $46.57 \pm 7.03(n=21)$ \\
Fruit fresh mass $(\mathrm{mg})$ & $2.00 \pm 0.22(n=25)$ & $70.45 \pm 8.6(n=6)$ \\
Number of seeds per fruit & $329 \pm 15$ & $>1000$ \\
Seed color & Brown & Yellow \\
Seed length $(\mathrm{mm})$ & $1.03 \pm 0.90(n=31)$ & $1.15 \pm 0.08(n=36)$ \\
Seed width $(\mathrm{mm})$ & $0.72 \pm 0.85(n=31)$ & $0.28 \pm 0.04(n=36)$ \\
Seed mass $(\mathrm{mg})$ & $0.21 \pm 0.04(n=100)$ & $0.31 \pm 0.00(n=90)$ \\
Seed shape & Reniform & Curved \\
\hline
\end{tabular}

The two invasive rats, $R$. rattus and $R$. exulans, were also considered. In Mont Panié area, adult $R$. rattus usually weigh around $177.4 \pm 30.1 \mathrm{~g} \quad( \pm \mathrm{SD}$, $\min =120 \mathrm{~g}, \max =263 \mathrm{~g}$ ) whereas adult $R$. exulans weigh around $69.5 \pm 12.8 \mathrm{~g}( \pm \mathrm{SD}$, $\min =50 \mathrm{~g}$ and $\max =95 \mathrm{~g}$ ). Ten adult $R$. rattus and four $R$. exulans were live trapped from two locations in forests near Nouméa (Ouen Toro dry forest, $22^{\circ} 18^{\prime} 36^{\prime \prime} \mathrm{S}$, $166^{\circ} 27^{\prime} 16^{\prime \prime} \mathrm{E}$ and Koghi rainforest, $22^{\circ} 10^{\prime} 38^{\prime \prime} \mathrm{S}$, $\left.166^{\circ} 30^{\prime} 30^{\prime \prime} \mathrm{E}\right)$. Each rat was held in an $40 \mathrm{~cm} \times$ $33 \mathrm{~cm} \times 28 \mathrm{~cm}$ or $60 \mathrm{~cm} \times 41 \mathrm{~cm} \times 37 \mathrm{~cm}$ individual metal mesh cage with bedding material and shelter. They were fed daily with mixed seeds and water was provided ad libitum.

Fruit consumption trials

All the feeding trials were performed from February through May 2015 with fresh fruits of Ficus and Freycinetia collected the day before. Before each feeding trial, all the cages were cleaned entirely to remove all remains of old faeces and uneaten food, in order to facilitate faeces collection. For native frugivores, the fruits were offered at the same time as their usual diet during their morning meal for one or 2 days depending on the species. Fruits were offered to five $D$. goliath, five $P$. ornatus, three $P$. tonganus, and six $P$. vetulus. Rats were deprived of their usual food (mixed seeds) $24 \mathrm{~h}$ before feeding trials to ensure that they consumed the tested fruits. The fruits were offered to four $R$. rattus and four $R$. exulans by offering fruits in each cage for 2 days. Rats were returned to their regular diet for at least $48 \mathrm{~h}$ between water was provided ad libitum. 
feeding trials. The faecal material was collected 24 and/or $36 \mathrm{~h}$ after consumption tests. In order to avoid any influence on germination induction or a hypothetical dormancy, faeces were stored at room temperature and were rapidly processed for germination tests in the $24 \mathrm{~h}$ following collection.

\section{Assessment of seed percent survival}

Visual inspection of faeces showed us that passage through native species digestive tracts did not destroy seeds. Moreover, D. pacifica, a species closely related to $D$. goliath, was observed defecating seeds up to at least $26 \mathrm{~mm}$ in diameter (McConkey et al. 2005), which is 20 times greater than the size of our tested seeds. Similarly, Pteropus conspicillatus can defecate seeds of at least $3.7 \mathrm{~mm}$ (Richards 1990). Consequently, we assumed that $100 \%$ of seeds ingested by native frugivores survived. However, flying foxes also spit out fruit pulp and some seeds after squeezing the juice from the fruits (Banack 1998; Shilton et al. 1999). Consequently a portion of the seeds may be not dispersed as far as the others. For invasive rats, in parallel to the consumption trials described above, a parallel experiment was set up to estimate the percentage of seed survival when seeds were ingested by the two species of rats (Williams et al. 2000; Shiels and Drake 2011). The number of seeds offered to rats was controlled by placing a precise number of seeds (100 seeds for Ficus and 50 seeds for Freycinetia), into a highly palatable bait composed of a mixture of crushed kibbles and peanut butter. This bait was offered individually to six $R$. rattus and four $R$. exulans but faeces could only be collected from five $R$. rattus and two $R$. exulans. All the droppings were carefully collected and inspected under a binocular microscope Leica MZ75 (4× magnification) in order to determine the percentages of damaged and undamaged seeds passing through the rat digestive tract. Seeds were considered undamaged when there was no visible change in the seed coat after passage through the digestive tract (Nogales et al. 2005). The removal of the calyx for the Ficus seeds was not considered to be damage.

\section{Germination trials}

Undamaged seeds were removed from native and invasive species faeces and were cleaned with tap water in order to avoid the potential effects of nutrients coming from faeces. Then seeds were quickly placed on water-wet cotton (humidity $100 \%$ ) in transparent Petri dishes. Four replicates of 25 seeds each (pooled from different individual plants and different individual animals) were tested for each treatment (Tassin et al. 2010; De Carvalho-Ricardo et al. 2014) except for $R$. exulans, for which very few seeds were obtained from the faeces ( $n=12$ for Ficus and $n=9$ for Freycinetia). There were six ingested seed treatments: $R$. rattus, $R$. exulans, $P$. ornatus, $P$. tonganus, $P$. vetulus, and $D$. goliath. Non ingested seeds, used as a control treatment, were manipulated in the same manner as ingested seeds. In the case of Ficus, two sets of control treatments were carried out: seeds without calyx ("no calyx" treatment) and seeds with calyx ("calyx" treatment). The reason for this was that when non-ingested seeds were hand-extracted, the seeds came with the calyx, though ingested seeds were found without the calyx. Freycinetia seeds do not have an individual calyx, so the second control group was not necessary in this case. The Petri dishes were placed in an incubator at $26.5^{\circ} \mathrm{C}$ with a natural photoperiod. Germination, defined as the emergence of $2 \mathrm{~mm}$ of the primary root (De Carvalho-Ricardo et al. 2014), was checked daily with a binocular microscope Leica MZ75 (4x magnification). Germination was monitored 15 days after sowing for Ficus and after 49 days for Freycinetia.

\section{Statistical analysis}

Seed percent survival was compared between rat and seed species with Chi-square tests for homogeneity with Yates' continuity correction. Concerning germination data analysis, for each Petri dish, the percentage of seeds that had germinated ("germinability") at the end of germination monitoring was calculated. Germination times were also measured. The "date of germination start" was noted as the day when the first seed had germinated in a Petri dish, and "T50" corresponded to the number of days required to reach $50 \%$ germination of the total number of sown seeds.

We assessed whether the germinability varied according to the different treatments using Generalized Linear Models (GLMs, quasibinomial family to account for over- or under-dispersion). We used a Chisquare test to assess the significance of the deviance change between the null model and the model with the 
"treatment" variable. GLMs were performed initially on data when grouped into four categories of treatments: controls (with and without calyx), invasive rats ( $R$. rattus and $R$. exulans), native pigeons (D. goliath) and native flying foxes ( $P$. ornatus, $P$. tonganus, and $P$. vetulus). Secondly, all treatments were compared by pairs using post hoc Tukey's tests, with the Holm correction (Aickin and Gensler 1996).

The germination times for each treatment were analyzed using Generalized Additive Models (GAMs) with the proportion of seed germinated as a response variable and quasibinomial errors to account for overor under-dispersion. Seed germination is not a linear function of time so we fitted change in number of seeds germinated with time using a thin plate regression spline (Wood 2006). We set the spline basis dimension ' $k$ ' to 6 to limit the complexity of the splines and prevent overfitting. GAM model predictions were then used to calculate the T50 of each treatment. All analyzes were performed under R Version 3.1.2 with packages multcomp and $\mathrm{mgcv}$.

\section{Results}

\section{Assessment of seed percent survival}

Visual inspections of faeces showed that $100 \%$ of seeds were undamaged after passing through native frugivore guts. By contrast, the seed survival results showed that the invasive rats destroyed a large proportion of the seeds that they ingested. For Ficus, the percentage of intact seeds passed through the $R$. rattus' digestive tract averaged $30.6 \pm 13.5 \%( \pm \mathrm{SD}$, $n=5$ ) and was significantly higher than the percentage of intact seeds that passed through $R$. exulans: $14 \pm 1.4 \% \quad\left( \pm \mathrm{SD}, \quad n=2, \quad \chi^{2}=7.02, \quad d f=1\right.$, $p=0.008)$. For Freycinetia, $30 \pm 19.0 \%( \pm \mathrm{SD}$, $n=5$ ) of seeds were found intact in $R$. rattus faeces and only $16 \pm 2.8 \% \quad\left( \pm \mathrm{SD}, \quad n=2 ; \quad \chi^{2}=4.77\right.$, $d f=1, p=0.029)$ in $R$. exulans faeces. No difference in survival rates was recorded between Ficus and Freycinetia species $\left(\chi^{2}=0.014, d f=1, p=0.905\right)$.

\section{Germinability}

The low number of seeds ( $n=12$ for Ficus and $n=9$ for Freycinetia) found in $R$. exulans faeces did not allow comparison of germinability and germination time with other treatments, so the $R$. exulans data were excluded from the statistical analysis of separate species. When analyzes were performed on treatment category, $R$. exulans data were grouped with $R$. rattus data in the "invasive rats" group.

For Ficus, the Chi-square test conducted in GLM results showed the existence of a significant effect of the treatment category, i.e. a difference in germinability among controls, native pigeons, native flying foxes and invasive rats (deviance explained by the model: $6.69 \%, p<0.001)$. Seeds passing through native flying foxes (Pteropus spp.) had a higher germinability than those passing through invasive rats $(p=0.012)$. However, no difference in germinability was recorded between invasive rats and the control treatments $(p=1)$ nor with native pigeons (D. goliath, $p=0.140)$. When all treatments were compared (Table 1a; Fig. 1), control seeds with calyx had lower germinability than control seeds without calyx $(p=0.013)$. Control seeds with calyx also had lower germinability than seeds ingested by Ducula goliath $(p=0.004)$, Pteropus ornatus $(p=0.005)$, P. tonganus $(p=0.005)$ and $P$. vetulus $(p=0.005)$. However, no significant difference was registered between control seeds with calyx and $R$. rattus $(p=0.355)$. For $R$. rattus, if we take into account the seed percent survival after gut passage, only $27 \%$ of ingested seeds are likely able to germinate.

For Freycinetia, the Chi-square test conducted in GLM results also showed the existence of a significant effect of the treatment category on the germinability (deviance explained by the model: $24.8 \%$, $p<0.001$ ). Seeds ingested by invasive species (i.e. Rattus spp.) had a $50 \%$ lower germinability than those ingested by native pigeons $(p<0.001)$, native flying foxes $(p<0.001)$ and the control seeds $(p<0.001)$. However, there was no difference between seeds ingested by native pigeons or native flying foxes and the control ( $p=0.191$ and $p=0.086$ respectively). When regarding native species, seeds ingested by $D$. goliath had a higher germinability followed by $P$. vetulus and $P$. tonganus. In contrast, $P$. ornatus treatment had the lowest germinability among native species (Table 1b; Fig. 1). Seeds ingested by $R$. rattus and $P$. ornatus had lower germinability than control seeds ( $p<0.001$ and $p=0.006$ respectively). Seeds subjected to $R$. rattus treatment had lower germinability than those subjected to D. goliath ( $p<0.001), P$. tonganus $(p<0.001)$ and $P$. vetulus treatments 
Fig. 1 Germinability (\% mean $\pm 1 \mathrm{SD}$ ) of Ficus racemigera and Freycinetia sulcata seeds according to the following treatments: controls (i.e. non-ingested seeds: $C N$ control without calyx, and $C C$ control with calyx), introduced omnivorous rodents: $R R R$. rattus, and native frugivorous species $(D G$ Ducula goliath, PT Pteropus tonganus, PO P. ornatus and $P V$ P. vetulus). Within a plant species, means sharing the same letter are not significantly different $(p>0.05)$

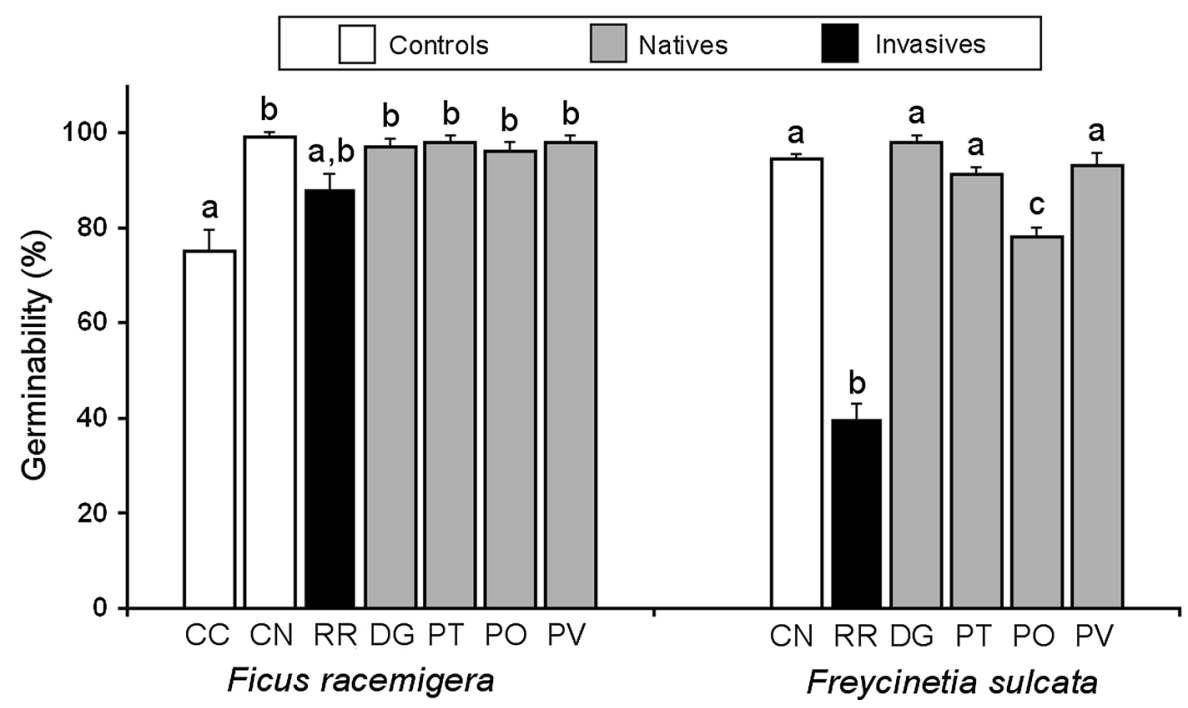

\section{Discussion}

$(p<0.001)$. For $R$. rattus, if we take into account the seed percent survival after gut passage, only $12 \%$ of ingested seeds are likely able to germinate.

\section{Germination time}

First germinations of Ficus seeds were registered 2 days after sowing for seeds subjected to passage through $D$. goliath whereas seeds subjected to $R$. rattus treatment began to germinate 5 days after sowing (Table 2a; Fig. 2). The last germination was recorded on day 13 for the control without calyx treatment. T50 (number of days required to reach $50 \%$ of the total number of sown seeds) differed for all treatments (Table 2a; Fig. 2). Whereas seeds ingested by native species germinated quickly $(4.35<\mathrm{T} 50<5.65$ days), seeds ingested by $R$. rattus reached T50 about 3 days later $($ T50 $=8.25$ days, Table 2a).

First germinations of Freycinetia seeds were registered 15 days after sowing for seeds ingested by $D$. goliath, $P$. ornatus and $P$. vetulus, whereas seeds ingested by $R$. rattus began to germinate on day 20 (Table 2b; Fig. 3). The last germinations were recorded on day 40 for $R$. rattus and Pteropus spp. treatments (Table 2b; Fig. 3). For the native species treatments, the smaller T50 s were recorded for $P$. vetulus $(\mathrm{T} 50=19.95$ days $)$, followed by $D$. goliath (T50 $=20.22$ days), and the control treatment (T50 = 22.36 days, Table $2 \mathrm{~b}$ ). As only $39.7 \%$ of seeds have germinated with $R$. rattus treatment, the T50 was not estimated.
Our results suggest that both native frugivorous vertebrates (D. goliath and Pteropus spp.) and introduced rodents (Rattus spp.) are potential dispersers of Ficus racemigera and Freycinetia sulcata seeds. However, seed dispersal by invasive rats is likely less efficient than by native frugivores as (1) more seeds were destroyed when passing through rats' digestive tracts than native frugivores', (2) germinability was lower for seeds passing through rat digestive tracts than native frugivores' and (3) T50 was longer when seeds were eaten by rats than by native frugivores. These results are consistent with other studies, which showed that invasive dispersers may be not as effective as native dispersers. For example, in the Canary Islands, invasive vertebrate frugivores defecated more damaged seeds of Rubia fruticosa than natives and fewer seeds germinated (Nogales et al. 2005). Invasive rats were found to be less effective than native species in dispersing Ficus prolixa in the Cook Islands (Staddon et al. 2010). This may be explained by the fact that, especially on islands, nonnative seed dispersers generally have a more generalist and opportunistic diet than many native species, which are more specialized and so adapted to disperse native plant species (Aslan et al. 2012).

Differences in seed percent survival, germinability and germination time, may occur because of frugivore morphology and behavior, or from fruit and seed characteristics (Traveset 1998). First, vertebrate's body size determines the size of seeds that can pass 
Table 2 Germinability ( $\%$, mean \pm SE) for each treatment and significant differences between treatments, day of first germination, and T50, i.e. number of days required to reach
$50 \%$ of the total number of sown seeds; for a) Ficus racemigera and b) Freycinetia sulcata

\begin{tabular}{|c|c|c|c|}
\hline Treatment & Germinability $(\%)$ & Day of first germination & T50 (days) \\
\hline \multicolumn{4}{|l|}{ (a) } \\
\hline ControlN (CN, $n=6)$ & $99.0 \pm 0.01 / \mathrm{CC}^{*}$ & 4 & 6.04 \\
\hline ControlC $(\mathrm{CC}, n=5)$ & $75.0 \pm 4.6 / \mathrm{CN}^{*}, \mathrm{DG}^{* *}, \mathrm{PO}^{* *}, \mathrm{PT}^{* *}, \mathrm{PV}^{* *}$ & 4 & 7.58 \\
\hline R. rattus $(\mathrm{RR}, n=4)$ & $88.0 \pm 3.4$ & 5 & 8.25 \\
\hline P. ornatus $(\mathrm{PO}, n=4)$ & $96.0 \pm 2.0 / \mathrm{CC}^{* *}$ & 2 & 5.65 \\
\hline P. tonganus $(\mathrm{PT}, n=4)$ & $98.0 \pm 1.4 / \mathrm{CC}^{* *}$ & 3 & 4.06 \\
\hline P. vetulus $(\mathrm{PV}, n=4)$ & $98.0 \pm 1.4 / \mathrm{CC}^{* *}$ & 3 & 4.10 \\
\hline $\begin{array}{l}\text { D. goliath }(\mathrm{DG}, n=4) \\
(b)\end{array}$ & $97.0 \pm 1.7 / \mathrm{CC}^{* *}$ & 4 & 4.56 \\
\hline Control $(\mathrm{CN}, \mathrm{n}=5)$ & $94.4 \pm 2.1 / \mathrm{PO} * *, \mathrm{RR}^{* * *}$ & 17 & 22.36 \\
\hline R. rattus $(R R, n=5)$ & $39.7 \pm 4.6 / \mathrm{DG}^{* * *}, \mathrm{PT}^{* * *}, \mathrm{PV}^{* * *}, \mathrm{PO}^{* * *}, \mathrm{CN}^{* * *}$ & 20 & 70 \\
\hline P. ornatus $(\mathrm{PO}, \mathrm{n}=4)$ & $78.0 \pm 4.2 / \mathrm{DG}^{* *}, \mathrm{RR}^{* * *}, \mathrm{PT} ., \mathrm{PV} *, \mathrm{CN}^{* *}$ & 15 & 23.16 \\
\hline P. tonganus $(\mathrm{PT}, \mathrm{n}=5)$ & $91.2 \pm 2.5 / \mathrm{PO} ., \mathrm{RR}^{* * *}$ & 18 & 26.21 \\
\hline$P$. vetulus $(P V, n=4)$ & $93.0 \pm 2.6 / \mathrm{PO}^{*}, \mathrm{RR}^{* * *}$ & 15 & 19.95 \\
\hline D. goliath $(\mathrm{DG}, \mathrm{n}=4)$ & $98.0 \pm 1.4 / \mathrm{PO} * *, \mathrm{RR}^{* *}$ & 15 & 20.22 \\
\hline
\end{tabular}

Treatment initials are used to indicate when a significant difference exists between treatments and the number of $*$ indicates the degree of significance $(.: p=0.05 ; * p<0.05$; ** $p<0.01$; *** $p<0.001$ ). Controls (non-ingested seeds) are denoted as ControlN when calyx was removed and ControlC when calyx was left

Fig. 2 Cumulative proportion of seeds $(\%)$ germinated of Ficus racemigera according to the treatment. Control CN control without calyx and Control CC Control with Calyx

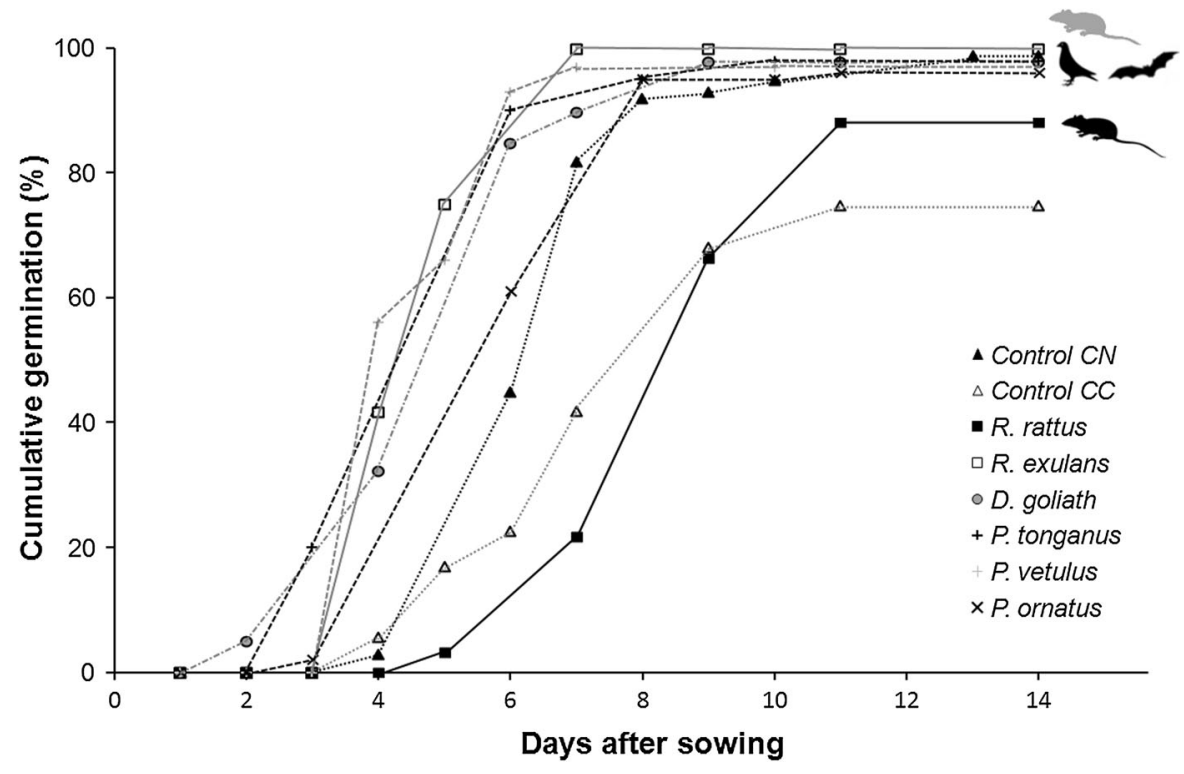

intact through its digestive tract (Traveset 1998; Pérez-Méndez et al. 2015). Rats are smaller than flying foxes or imperial pigeons, and this difference may partly explain the lower percent survival for seeds in the rat treatment. The size limit for seeds passing intact through the digestive tract is reported to be 2.0-2.5 mm for R. rattus and $0.11 \mathrm{~mm}$ for $R$. exulans (Williams et al. 2000; Shiels 2011) whereas a limit of 
Fig. 3 Cumulative proportion of seeds (\%) germinated of Freycinetia sulcata according to the treatment

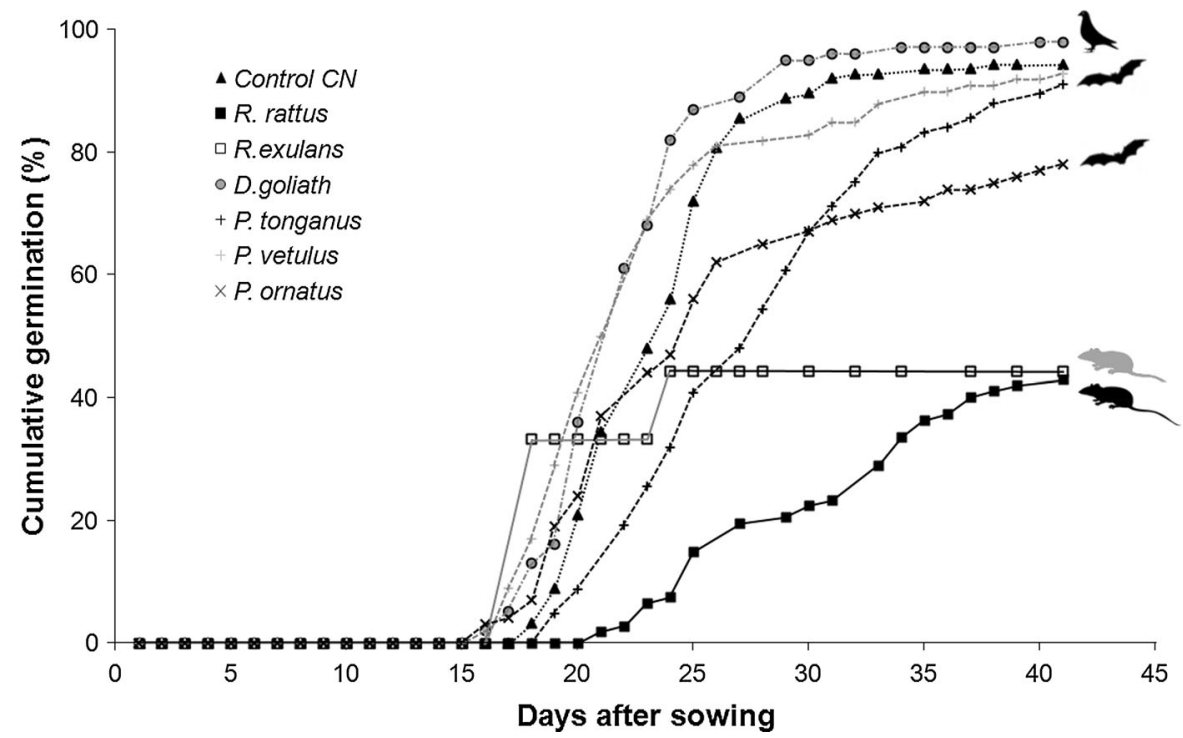

1983; Sakaguchi et al. 1987). The longer time passed in the rat digestive tract may lead to an excessive seed chemical abrasion, which may explain the lower seed germinability (Traveset 1998).

In our experimentation, germinability differences between native and invasive treatments were higher for Freycinetia sulcata than for Ficus racemigera. As noted by Traveset (1998), a frugivorous species can have different effects on seed germination depending on fruit and seed traits, such as size, shape, pulp consistency, seed coat thickness, etc. Seeds with high permeability and a thin coat may germinate more rapidly thanks to faster water absorption (Traveset et al. 2008). Freycinetia seeds have thicker coats than Ficus (personal observation) which may explain why the first germination was on day 15 for Freycinetia and on day 2 for Ficus. For Ficus, a higher germinability was observed when seeds were ingested or when the calyx was removed. In other Ficus species, the effect of seed passage through various vertebrates (primates, bats and birds) has also generally been enhancement of germination (Traveset 1998). Likewise, regarding morphological features of Freycinetia fruits, the hypothesis that seeds need to be released from the mucus sheath through ingestion by frugivores is a possibility, but, to the best of our knowledge, it has never been experimentally demonstrated before.

When compared with non-ingestion of seeds and ingestion by flying foxes, ingestion by the native imperial pigeon (Ducula goliath) seemed to better 
enhance germination for Freycinetia. By contrast, for Ficus, the native pigeons did not have a greater facilitative effect than when no ingestion or ingestion by flying foxes occurred. The effects of birds on germination are variable according to seed species, sometimes enhancing and other times inhibiting germination, whereas no influence of ingestion by flying foxes on seed germinability has been reported (Traveset 1998). However, flying foxes and frugivorous pigeons are recognized to play an important role in seed dispersal, as they can allow seeds to germinate far from the mother plant (Galindo-Gonzalez et al. 2000; Olesen and Valido 2004; Nakamoto et al. 2009). Ficus is a key genus for flying foxes; for example, Pteropus dasymallus in Japan consumed nine different species of Ficus (Nakamoto et al. 2009), and Pteropus conspicillatus in Australia ate 13 different species of Ficus (Parsons et al. 2006). Ficus species were frequently eaten by Pteropus conspicillatus in a study conducted in the Australian wet tropics (Parsons et al. 2006). In the Cook Islands, native pigeons and doves appeared to be the most effective native dispersers of Ficus prolixa (Staddon et al. 2010) and Ducula galeata fed principally on fruits of Ficus in the Marquesas archipelago (Blanvillain and Thorsen 2003). Likewise, Ficus racemigera may be well dispersed by native Pteropus spp. and Ducula goliath in New Caledonia. Almost no information on $\mathrm{Fr}$ eycinetia germination or dispersal is known except that Freycinetia spp. can be dispersed by bats (Van Der Pijl 1957; Lord 1991) and that Ducula goliath was observed feeding on Freycinetia arborea in Mont Panié (personal observation), a Freycinetia sulcata closely related species.

Seed survival and germination are just two of many required steps for the development of a new plant individual. Another important condition is that animals have to defecate in suitable sites for germination (Calviño-Cancela 2004). To avoid competition, it is better for seeds to be taken away from the mother tree. Ducula pigeons and flying foxes help fulfill this condition by travelling long distances. In New Caledonia, Boissenin and Brescia (2014) showed that by night $P$. ornatus and $P$. tonganus equipped with satellite transmitters can fly distances between 8 to $15 \mathrm{~km}$, from their day roosts to feeding areas. In contrast, rats are territorial and do not travel long distances (Bramley 2014; Ringler et al. 2014). On an island in the Indian Ocean, spool-line experiments showed that $R$. rattus made trips from 63 to $192 \mathrm{~m}$ inside the forest (Ringler et al. 2014). In a NewCaledonian rainforest, spatially explicit capture-recapture analyzes showed that $R$. rattus and $R$. exulans home ranges vary from 0.41 to 1.34 ha (Duron et al. unpublished results). These results suggest that invasive rats are not able to disperse seeds as far as native species. However, small movements may still help plants to avoid competition with siblings and, spread of pathogens and may allow colonization of treefall gaps (Traveset et al. 2014).

In view of these elements, invasive rats do not seem to be efficient dispersers when native pigeons and flying foxes are still present. Moreover, some species of passerines and Squamata are frugivorous or partly frugivorous and may play a disperser role in the rainforest, but very little is actually known. Nonetheless, the question of the importance of rats in the dispersal process is crucial as invasive rat populations are more and more subject to management operations i.e. eradication (complete removal) or control (rat population reduction). In New Caledonian rainforest, dispersal services for both species studied seem wellfulfilled by native flying foxes and imperial pigeons. However, flying foxes and imperial pigeons are popular game species in New Caledonia, and their populations are globally considered as decreasing (Mickelburgh et al. 1992; Barré and Dutson 2000; Brescia 2007). Low population densities i.e. less competition between individuals can lead to a cessation of dispersal function (McConkey and Drake 2006). If native dispersers' populations become small or disappear entirely, the role of invasive rats in seed dispersal may become more important (Staddon et al. 2010).

In New Caledonia, an assessment has been undertaken to determine whether controlling invasive rats would be beneficial for native biodiversity. Studying the trophic interactions and functional roles of invasive rats before making decisions about their management is crucial in order to avoid causing undesirable changes in the ecosystem (Zavaleta et al. 2001). Today, controlling rats in New Caledonia does not seem to pose a threat to essential seed dispersal services. Assuming that fruit resources may be limited, controlling rats may reduce competition with native frugivores. In some studies, a decrease in competition was hypothesized to foster seed dispersal (Bourgeois et al. 2005; Chimera and Drake 2010; 
Shiels 2011; Jordaan et al. 2011), but to the best of our knowledge, this has not been demonstrated. Moreover, in some cases, competition may reduce seed dispersal by reducing the necessity of longer travels for animals to find food (McConkey and Drake 2006; McConkey and O'Farrill 2016). Consequently, it is difficult to predict the effect of rat control on seed dispersal. Stringent management measures to protect native frugivores should be reinforced in order to maintain frugivore populations at high densities, in order to ensure continuing seed dispersal services.

Acknowledgments This study was funded by the Northern Province of New Caledonia to REFCOR project (Réponses des Ecosystèmes Forestiers au COntrôle des Rongeurs, Convention No 12C240). We are grateful to Mélanie Boissenin, Bruno Fogliani, Charly Zongo from IAC (Institut Agronomique NéoCalédonien) and Philippe Marmey from IRD (Institut de Recherche pour le Développement) for the valuable discussions about the experiment. We thank Almudena Lorenzo, Oriane Lallemand and Marianne Bonzon from Michel Corbasson Zoological and Forest Park of Noumea, "Direction de l'Environnement" of the Southern Province of New Caledonia, who allowed us to work with imperial pigeons and flying foxes. We also thank Edouard Bourguet and Frédéric Rigault for their help in collecting fruits, Josepho Bahormal for his help in taking care of rats, and Carol Frost for English advice and useful comments on the paper draft.

\section{References}

Aickin M, Gensler H (1996) Adjusting for multiple testing when reporting research results: the Bonferroni vs Holm methods. Am J Pub Health 86(5):726-728

Aslan CE, Zavaleta ES, Croll D, Tershy B (2012) Effects of native and non-native vertebrate mutualists on plants. Conserv Biol 26:778-789. doi:10.1111/j.1523-1739.2012. 01885.x

Atkinson IAE (1985) The spread of commensal species of Rattus to oceanic islands and their effects on avifaunas. ICPB Tech Publ 3:35-81

Balouet JC (1991) The fossil vertebrate record of New Caledonia. In: Vickers-Rich P, Monaghan JM, Baird RF, Rich TH (eds) Vertebrate palaeontology of Australasia. Pioneer Design Studio/Monash University Publicartions Committee, Melbourne, pp 1383-1409

Balouet JC, Olson SL (1989) Fossil birds from late Quaternary deposits in New Caledonia. Smithsonian Institution Press, Washington

Banack SA (1998) Diet selection and resource use by flying foxes (genus Pteropus). Ecology 79:1949-1967

Barnea A, Yom-Tov Y, Friedman J (1991) Does ingestion by birds affect seed germination? Funct Ecol 5:394-402. doi: $10.2307 / 2389811$

Barré N, Dutson G (2000) Oiseaux de Nouvelle Calédonie. Liste commentée. Alauda 68(supplement):49p
Barré N, de GWichatitsky M, Lecoq R, Maillard J-C (2003) Contribution to the knowledge of the New Caledonian imperial pigeon Ducula goliath (Gray, 1859), with emphasis on sexual dimorphism. Notornis 50:155-160

Beauvais M-L, Coléno A, Jourdan H (eds) (2006) Invasive species in the New Caledonian archipelago. IRD, Paris

Blackburn TM, Cassey P, Duncan RP et al (2004) Avian extinction and mammalian introductions on oceanic islands. Science 305:1955-1958

Blanvillain C, Thorsen M (2003) The biology of the critically endangered Marquesan Imperial-Pigeon (Ducula galeata), Nuku Hiva, Marquesas Archipelago (French Polynesia). EMU 103:381-386. doi:10.1071/MU01022

Boissenin M, Brescia F (2014) Movements of the New Caledonian over-hunted flying foxes: implications for management. In: 16th Australasian bat society conference. Townsville, Australia

Boissenin M, Gomez S, Barré N et al (2006) Interactions entre l'avifaune frugivore et la flore ligneuse en forêt sèche de Nouvelle- Calédonie. IAC, Dry forest programme, Nouméa, New Caledonia

Bourgeois K, Suehs CM, Vidal E, Médail F (2005) Invasional meltdown potential: facilitation between introduced plants and mammals on French Mediterranean islands. Ecoscience 12:248-256

Bramley GN (2014) Home ranges and interactions of kiore (Rattus exulans) and Norway rats (R. norvegicus) on Kapiti Island, New Zealand. N Z J Ecol 38:328-334

Brescia F (2007) Amélioration des connaissances et recommandations pour la sauvegarde des populations de Mégachiroptères (roussettes) en Province Sud de la Nouvelle-Calédonie. Institut Agronomique néo-Calédonien

Burrows CJ (1996) Germination behaviour of seeds of the New Zealand woody species Coprosma foetidissima, Freycinetia baueriana, Hoheria angustifolia, and Myrsine australis. N Z J Bot 34:499-508. doi:10.1080/0028825X.1996. 10410130

Calviño-Cancela M (2004) Ingestion and dispersal: direct and indirect effects of frugivores on seed viability and germination of Corema album (Empetraceae). Acta Oecol 26:55-64. doi:10.1016/j.actao.2004.03.006

Capizzi D, Bertolino S, Mortelliti A (2014) Rating the rat: global patterns and research priorities in impacts and management of rodent pests. Mammal Rev 44:148-162. doi:10.1111/ mam.12019

Carpenter RJ, Read J, Jaffré T (2003) Reproductive traits of tropical rain-forest trees in New Caledonia. J Trop Ecol 19:351-365. doi:10.1017/S0266467403003407

Caut S, Angulo E, Courchamp F (2008) Dietary shift of an invasive predator: rats, seabirds and sea turtles. J Appl Ecol 45:428-437. doi:10.1111/j.1365-2664.2007.01438.x

Chimera CG, Drake DR (2010) Patterns of seed dispersal and dispersal failure in a hawaiian dry forest having only introduced birds: introduced birds, invasion, and dispersal failure. Biotropica 42:493-502. doi:10.1111/j.1744-7429. 2009.00610.x

Clout MN, Tilley JAV (1992) Germination of miro (Prumnopitys ferruginea) seeds after consumption by New Zealand pigeons (Hemiphaga novaeseelandiae). N Z J Bot 30:25-28. doi:10.1080/0028825X.1992.10412882 
Courchamp F, Chapuis J-L, Pascal M (2003) Mammal invaders on islands: impact, control and control impact. Biol Rev 78:347-383. doi:10.1017/S1464793102006061

De Carvalho-Ricardo MC, Uieda W, Fonseca RCB, Rossi MN (2014) Frugivory and the effects of ingestion by bats on the seed germination of three pioneering plants. Acta Oecol 55:51-57. doi:10.1016/j.actao.2013.11.008

Flannery TF (1995) Mammals of the South-West Pacific and Moluccan Islands. Cornell University Press, Ithaca, NY

Foster JT, Robinson SK (2007) Introduced birds and the fate of Hawaiian rainforests. Conserv Biol 21:1248-1257

Funakoshi K, Watanabe H, Kunisaki T (1993) Feeding ecology of the northern Ryukyu fruit bat, Pteropus dasymallus dasymallus, in a warm-temperate region. $\mathrm{J}$ Zool 230:221-230. doi:10.1111/j.1469-7998.1993.tb02684.x

Galindo-Gonzalez J, Guevara S, Sosa VJ (2000) Bat- and birdgenerated seed rains at isolated trees in pastures in a tropical rainforest. Conserv Biol 14:1693-1703

Grant-Hoffman MN, Barboza PS (2010) Herbivory in invasive rats: criteria for food selection. Biol Invasions 12:805-825

Heer K, Albrecht L, Kalko EKV (2010) Effects of ingestion by neotropical bats on germination parameters of native freestanding and strangler figs (Ficus sp., Moraceae). Oecologia 163:425-435. doi:10.1007/s00442-010-1600-x

Jordaan LA, Johnson SD, Downs CT (2011) The role of avian frugivores in germination of seeds of fleshy-fruited invasive alien plants. Biol Invasions 13:1917-1930. doi:10. 1007/s10530-011-0013-z

Jordano P (2014) Fruits and frugivory. In: Gallagher RS (ed) Seeds: the ecology of regeneration in plant communities, 3rd edn. CABI International, Oxfordshire, pp 10-61

Kaiser-Bunbury CN, Traveset A, Hansen DM (2010) Conservation and restoration of plant-animal mutualisms on oceanic islands. Perspect Plant Ecol Evol Syst 12:131-143

Kelly D, Robertson AW, Ladley JJ, et al (2006) Relative (un) importance of introduced animals as pollinators and dispersers of native plants. In: Biological invasions in New Zealand. Springer, 227-245

Lever C (1985) Naturalized mammals of the world. Longman, London

Lord JM (1991) Pollination and seed dispersal in Freycinetia baueriana, a dioecious liane that has lost its bat pollinator. N Z J Bot 29:83-86. doi:10.1080/0028825X.1991. 10415545

Markl JS, Schleuning M, Forget PM et al (2012) Meta-Analysis of the Effects of Human Disturbance on Seed Dispersal by Animals: human Effects on Animal Seed Dispersal. Conserv Biol 26:1072-1081. doi:10.1111/j.1523-1739.2012. 01927.x

McConkey KR, Drake DR (2006) Flying foxes cease to function as seed dispersers long before they become rare. Ecology 87:271-276

McConkey KR, O’Farrill G (2016) Loss of seed dispersal before the loss of seed dispersers. Biol Conserv 201:38-49. doi:10.1016/j.biocon.2016.06.024

McConkey KR, Meehan HJ, Drake DR (2005) Seed dispersal by Pacific pigeons (Ducula pacifica) in Tonga, western Polynesia. Emu 104:369-376

Meyer J-Y, Butaud J-F (2008) The impacts of rats on the endangered native flora of French Polynesia (Pacific Islands): drivers of plant extinction or coup de grâce species? Biol Invasions 11:1569-1585. doi:10.1007/ s10530-008-9407-y

Mickelburgh S, Hutson AM, Racey PA (1992) Old World fruit bats: An action plan for their conservation. IUCN/SSC Chiroptera Specialist Group, Gland

Mittermeier RA, Turner WR, Larsen FW et al (2011) Global biodiversity conservation: the critical role of hotspots. In: Zachos FE, Habel JC (eds) Biodiversity Hotspots. Springer, Berlin Heidelberg, pp 3-22

Morat P, Jaffré T, Tronchet $\mathrm{F}$ et al (2012) Le référentiel taxonomique Florical et les caractéristiques de la flore vasculaire indigène de la Nouvelle-Calédonie. Adansonia 34:179-221. doi:10.5252/a2012n2a1

Nakamoto A, Kinjo K, Izawa M (2009) The role of Orii's flyingfox (Pteropus dasymallus inopinatus) as a pollinator and a seed disperser on Okinawa-jima Island, the Ryukyu Archipelago, Japan. Ecol Res 24:405-414. doi:10.1007/ s11284-008-0516-y

Nogales M, Nieves C, Illera JC et al (2005) Effect of native and alien vertebrate frugivores on seed viability and germination patterns of Rubia fruticosa (Rubiaceae) in the eastern Canary Islands. Funct Ecol 19:429-436

Olesen JM, Valido A (2004) Lizards and birds as generalized pollinators and seed dispersers of island plants. Ecol Insul Ecol Cabil Insul Palma Asoc Espanola Ecol Terr 229-249

Parsons JG, Cairns A, Johnson CN et al (2006) Dietary variation in spectacled flying foxes (Pteropus conspicillatus) of the Australian Wet Tropics. Aust J Zool 54:417-428. doi:10. 1071/ZO06092

Pattemore DE, Wilcove DS (2011) Invasive rats and recent colonist birds partially compensate for the loss of endemic New Zealand pollinators. Proc R Soc B Biol Sci rspb20112036

Pérez-Méndez N, Jordano P, Valido A (2015) Downsized mutualisms: consequences of seed dispersers' body-size reduction for early plant recruitment. Perspect Plant Ecol Evol Syst 17:151-159. doi:10.1016/j.ppees.2014.12.001

Perrin MR, Maddock AH (1983) Preliminary investigations of the digestive processes of the white-tailed rat Mystromys albicaudatus (Smith 1834). Afr J Zool 18:128-133

Reid S, Armesto JJ (2011) Avian gut-passage effects on seed germination of shrubland species in Mediterranean central Chile. Plant Ecol 212:1-10. doi:10.1007/s11258-0109796-8

Richards GC (1990) The spectacled flying-fox, Pteropus conspicillatus (Chiroptera: Pteropodidae), in North Queensland. 2. Diet, seed dispersal and feeding ecology. Aust Mammal 13:25-31

Ringler D, Russell J, Jaeger A et al (2014) Invasive rat space use on tropical islands: implications for bait broadcast. Basic Appl Ecol 15:179-186. doi:10.1016/j.baae.2014.01.005

Sakaguchi EI, Itoh H, Uchida S, Horigome T (1987) Comparison of fibre digestion and digesta retention time between rabbits, guinea-pigs, rats and hamsters. $\mathrm{Br} \mathrm{J}$ Nutr 58:149-158

Scheiner S, Willig M (2011) The theory of ecology. University of Chicago Press, Chicago

Shiels AB (2011) Frugivory by introduced black rats (Rattus rattus) promotes dispersal of invasive plant seeds. Biol Invasions 13:781-792 
Shiels AB, Drake DR (2011) Are introduced rats (Rattus rattus) both seed predators and dispersers in Hawaii? Biol Invasions 13:883-894. doi:10.1007/s10530-010-9876-7

Shiels AB, Flores CA, Khamsing A et al (2012) Dietary niche differentiation among three species of invasive rodents (Rattus rattus, R. exulans, Mus musculus). Biol Invasions 15:1037-1048. doi:10.1007/s10530-012-0348-0

Shiels AB, Pitt WC, Sugihara RT, Witmer GW (2014) Biology and impacts of Pacific island invasive species. 11. Rattus rattus the Black Rat (Rodentia: Muridae). Pac Sci 68:145-184. doi:10.2984/68.2.1

Shilton LA, Altringham JD, Compton SG, Whittaker RJ (1999) Old World fruit bats can be long-distance seed dispersers through extended retention of viable seeds in the gut. Proc R Soc B Biol Sci 266:219-223. doi:10.1098/rspb.1999. 0625

Staddon SC, Compton SG, Portch A (2010) Dispersal of fig seeds in the Cook Islands: introduced frugivores are no substitutes for natives. Biodivers Conserv 19:1905-1916. doi:10.1007/s10531-010-9811-3

Stone BC, Huynh K-L, Poppendieck H-H (1998) Pandanaceae. In: Kubitzki PDK (ed) Flowering Plants · Monocotyledons. Springer, Berlin Heidelberg, pp 397-404

Sugihara RT (1997) Abundance and diets of rats in two native Hawaiian forests. Pac Sci 51:189-198

Tassin J, Boissenin M, Barré N (2010) Can Ptilinopus greyii (Columbidae) disperse seeds in New Caledonia's dry forests? Pac Sci 64:527-532. doi:10.2984/64.4.527

Traveset A (1998) Effect of seed passage through vertebrate frugivores' guts on germination: a review. Perspect Plant Ecol Evol Syst 1:151-190

Traveset A, Richardson D (2006) Biological invasions as disruptors of plant reproductive mutualisms. Trends Ecol Evol 21:208-216. doi:10.1016/j.tree.2006.01.006
Traveset A, Rodríguez-Pérez J, Pías B (2008) Seed trait changes in dispersers'guts and consequences for germination and seedling growth. Ecology 89:95-106

Traveset A, Nogales M, Alcover JA et al (2009) A review on the effects of alien rodents in the Balearic (Western Mediterranean Sea) and Canary Islands (Eastern Atlantic Ocean). Biol Invasions 11:1653-1670. doi:10.1007/s10530-0089395-y

Traveset A, Heleno R, Nogales M (2014) The ecology of seed dispersal. In: Gallagher RS (ed) Seeds: the ecology of regeneration in plant communities, 3rd edn. CABI International, Oxfordshire, pp 62-93

Tylianakis JM, Didham RK, Bascompte J, Wardle DA (2008) Global change and species interactions in terrestrial ecosystems. Ecol Lett 11:1351-1363. doi:10.1111/j.14610248.2008.01250.x

Van Der Pijl L (1957) The dispersal of plants by bats (chiropterochory). Acta Bot Neerlandica 6:291-315

Whittaker RJ, Fernandez-Palacios JM (2007) Island biogeography. Ecology, evolution, and conservation. Oxford University Press, New York

Williams PA, Karl BJ, Bannister P, Lee WG (2000) Small mammals as potential seed dispersers in New Zealand. Austral Ecol 25:523-532

Wood S (2006) Generalized Additive Models: An Introduction with R. CRC Press, Boca Raton

Wotton DM, Clout MN, Kelly D (2008) Seed retention times in the New Zealand pigeon (Hemiphaga novaezeelandiae novaeseelandiae). N Z J Ecol 32:1-6

Zavaleta ES, Hobbs RJ, Mooney HA (2001) Viewing invasive species removal in a whole-ecosystem context. Trends Ecol Evol 16:454-459 